Article

\title{
Solvent engineering of spin-coating solutions for planar-structured high-efficiency perovskite solar cells
}

\author{
Bing Cai a,b, Wen-Hua Zhang b, Jieshan Qiu a,* \\ a Carbon Research Laboratory, Liaoning Key Laboratory for Energy Materials and Chemical Engineering, State Key Laboratory of Fine Chemicals, \\ Dalian University of Technology, Dalian 116024, Liaoning, China \\ b State Key Laboratory of Catalysis, Dalian Institute of Chemical Physics, Chinese Academy of Sciences, Dalian National Laboratory for Clean Energy, \\ Dalian 116023, Liaoning, China
}

\section{A R T I C L E I N F O}

\section{Article history:}

Received 21 May 2015

Accepted 16 June 2015

Published 20 August 2015

\section{Keywords:}

Perovskite

Film

Solar cell

Solvent engineering

Morphology

Device performance

\begin{abstract}
A B S T R A C T
Control of the morphology and coverage of high-quality perovskite films is the main issue affecting planar-structured perovskite solar cells fabricated by solution processing. In this work, the solvent engineering of mixed solutions for spin-coating uniform perovskite thin films was investigated in detail by adding different ratios of $N, N$-dimethylformamide (DMF) or $\gamma$-butyrolactone (GBL) to dimethyl sulfoxide (DMSO). The morphology and film thickness of the resulting perovskite films were found to be significantly altered. At $20 \% \sim 40 \%$ (volume fraction) of $\mathrm{N}, \mathrm{N}$-dimethylformamide mixed with DMSO, micrometer scale grains and reduced grain boundaries were observed on the highly uniform perovskite thin films. The optimized planar-structured perovskite solar cells showed power conversion efficiency as high as $16.5 \%$ and a stabilized efficiency of $14.4 \%$ at a fixed forward bias of $0.88 \mathrm{~V}$.
\end{abstract}

(C) 2015, Dalian Institute of Chemical Physics, Chinese Academy of Sciences. Published by Elsevier B.V. All rights reserved.

\section{Introduction}

Since the first introduction of sensitized solar cells with liquid configuration in 2009 [1], organolead halide perovskite materials have garnered great attention around the world. Using different compositions, these perovskite materials [2-5] have been successfully applied as light absorbers in photovoltaic devices with various support materials [6-11] and structures [1,2,12-17]. Among them, mesoscopic structures based on metal oxides $\left(\mathrm{TiO}_{2}[3,4,6-9,12], \mathrm{Al}_{2} \mathrm{O}_{3}\right.$ [2,18], etc.) are probably the most studied category, and exhibit very impressive photovoltaic performance. The unusual properties of these perovskite materials, such as large diffusion length [19-21] and low recombination [12,22] enable the fabrication of planar-structured thin film photovoltaic devices with excellent performance, and promise for applications in flexible [23,24] and tandem solar cells $[25,26]$. However, in comparison with sensitized mesoscopic structured cells, fabricating high-quality perovskite films without supporting mesoscopic metal oxides is a greater challenge $[27,28]$.

The vacuum thermal evaporation adopted by Snaith's group [17] is a good approach which yields perovskite films with uniform thickness and high device efficiency. However, use of this method greatly increases manufacturing costs and thus is unfavorable for large-scale solar cell fabrication. One step spin-coating is a simple way to prepare perovskite materials, but does not produce films with homogeneous grain size and uniformity. Two-step deposition processes including sequential solution deposition [29,30] and vapor-assisted two-step reaction $[31,32]$ have been exploited to make perovskite films with

\footnotetext{
* Corresponding author. E-mail: jqiu@dlut.edu.cn

This work was partly supported by the National Natural Science Foundation of China $(21336001,20873141)$.

DOI: 10.1016/S1872-2067(15)60929-9 | http://www.sciencedirect.com/science/journal/18722067 | Chin. J. Catal., Vol. 36, No. 8, August 2015
} 
high uniformity, but these multi-step deposition procedures extend the overall processing time. Cheng's group [33] invented a one-step, fast crystallization method by drop-casting chlorobenzene (CB) during the spin-coating of perovskite $\mathrm{N}, \mathrm{N}$-dimethylformamide (DMF) solution to quickly induce crystallization, yielding very flat, highly uniform $\mathrm{CH}_{3} \mathrm{NH}_{3} \mathrm{PbI}_{3}$ $\left(\mathrm{MAPbI}_{3}\right)$ thin films. Seok's group [34] developed a similar spin-coating and drop-casting method, mainly focused on mesoscopic systems. A mixture of $\gamma$-butyrolactone (GBL) and dimethyl sulfoxide (DMSO) was used as the solvent for the perovskite, followed by toluene drop-casting. The introduction of DMSO caused a uniform $\mathrm{CH}_{3} \mathrm{NH}_{3} \mathrm{I}-\mathrm{PbI}_{2}$-DMSO intermediate phase film $[34,35]$ to form, which enabled the subsequent formation of a highly uniform and dense $\mathrm{MAPbI}_{3}$ film after annealing. GBL was reported to work solely as a high-evaporation component in this mixed solvent GBL-DMSO. Despite these findings, it is still necessary to carry out a systematic study of solvent engineering for perovskite materials.

Herein, we have investigated the influence of the type and proportion of the mixed solvents on the morphology of $\mathrm{MAPbI}_{3}$ thin film in detail using a modified spin-coating method. We found that adding $20 \% \sim 40 \%$ of DMF in the solvent mixture (DMF-DMSO) led to uniform $\mathrm{MAPbI}_{3}$ films with large grain size and increased film thickness. As-prepared $\mathrm{MAPbI}_{3}$ thin films were further assembled into planar-structured perovskite solar cells, which exhibited power conversion efficiency (PCE) as high as $16.5 \%$. Because the entire solar cell fabrication process was carried out at temperatures lower than $100^{\circ} \mathrm{C}$, the present fabrication method could be easily extended to flexible photovoltaic devices on plastic substrates.

\section{Experimental}

\subsection{Materials}

$\mathrm{PbI}_{2}$, lithium bis(trifluoromethanesulfonyl)imide (Li-TFSI), 4-tert-butyl pyridine (tBP), $\mathrm{CB}$, and acetonitrile were purchased from Sigma-Aldrich. Spiro-MeOTAD was provided by Shenzhen Feiming Technology Co., China. $\mathrm{CH}_{3} \mathrm{NH}_{3} \mathrm{I}$ (MAI) was synthesized according to a literature method [31]. GBL was purchased from Aladdin Industrial Inc., Shanghai, China. DMF, DMSO and all other reagents were purchased from Sino Chem. Co., China.

\subsection{Preparation of $\mathrm{TiO}_{2}$ blocking layer}

A $\mathrm{TiO}_{2}$ dense film, working as both a hole blocking layer (bl- $\mathrm{TiO}_{2}$ ) and electron extraction layer, was synthesized by $\mathrm{TiCl}_{4}$ chemical bath deposition according to the literature [36]. FTO glass substrates were ultrasonically cleaned with water, ethanol, acetone and 2-propanol, and then treated in an $\mathrm{O}_{2}$-plasma cleaner for $30 \mathrm{~min}$. The treated FTO substrates were immersed into $200 \mathrm{mmol} / \mathrm{L} \mathrm{TiCl}_{4}$ aqueous solution and kept at $70{ }^{\circ} \mathrm{C}$ for $1 \mathrm{~h}$, followed by washing with DI water and ethanol, and were finally dried at $100^{\circ} \mathrm{C}$ for $1 \mathrm{~h}$ before further use.
The spin-coating solution was prepared by dissolving 0.530 $\mathrm{g} \mathrm{PbI}_{2}$ and $0.183 \mathrm{~g} \mathrm{MAI}$ in $1 \mathrm{~mL}$ of DMF-DMSO or GBL-DMSO solvent mixtures of varying ratios (volume fractions) under stirring at $60{ }^{\circ} \mathrm{C}$ for $12 \mathrm{~h}$. The resulting solutions were spin-coated onto the prepared $\mathrm{bl}_{-} \mathrm{TiO}_{2}$ layer at $1000 \mathrm{rpm}$ for 10 $\mathrm{s}$ and $6000 \mathrm{rpm}$ for $55 \mathrm{~s}$ at room temperature $\left(\sim 20^{\circ} \mathrm{C}\right)$. During the second spin-coating step, after $25 \mathrm{~s}$ of spin-coating at 6000 rpm, $0.75 \mathrm{~mL}$ chlorobenzene was quickly dropped onto the center of the spinning substrate. After annealing for $15 \mathrm{~min}$ on a $100{ }^{\circ} \mathrm{C}$ hotplate, the as-prepared films turned from colorless to dark brown, indicative of the formation of $\mathrm{MAPbI}_{3}$ perovskite. A spiro-MeOTAD solution was prepared by dissolving $72.3 \mathrm{mg}$ of spiro-MeOTAD in $1 \mathrm{~mL}$ of chlorobenzene, into which $27.8 \mu \mathrm{L}$ of tBP and 17.5 $\mu \mathrm{L}$ of Li-TFSI solution (520 mg Li-TFSI in $1 \mathrm{~mL}$ acetonitrile) were added. The spiro-MeOTAD solution was spin-coated on the perovskite film at $5000 \mathrm{rpm}$ for $30 \mathrm{~s}$. Finally, a gold electrode was thermally evaporated onto the spiro-MeOTAD-coated film to a thickness of $\sim 60 \mathrm{~nm}$.

\subsection{Characterization}

The morphological characterization of the perovskite film was carried out by scanning electron microscopy (SEM; FEI Quanta200F scanning electron microscope). The crystal phase was identified by X-ray diffraction (XRD; X'Pert Pro) using $\mathrm{Cu}-K_{\alpha}$ radiation of $\lambda=0.154 \mathrm{~nm}$. The UV-Vis absorption of the film was measured on a Varian Cary 5000 UV-Vis spectrophotometer. The photocurrent density-voltage $(J-V)$ characteristics of the solar cells were obtained using a Keithley 2400 source meter under illumination with simulated sunlight (AM $1.5,100 \mathrm{~mW} / \mathrm{cm}^{2}$ ) provided by a solar simulator (Newport 69907) with an AM 1.5 filter. A metal aperture of $0.09 \mathrm{~cm}^{2}$ was used during the measurement to define the active area of the device and avoid light scattering through the sides. The incident photon-to-current efficiency (IPCE) of the device was measured on a QTest Station 2000ADI system (Crowntech Inc. USA) in AC mode with a tungsten-halogen lamp (150 W) as the light source. The monochromatic light intensity used in the IPCE efficiency measurements was calibrated with a reference silicon photodiode.

\section{Results and discussion}

In this work, DMSO functioned both as a solvent and as a coordination reagent in the form of a $\mathrm{PbI}_{2}-\mathrm{CH}_{3} \mathrm{NH}_{3} \mathrm{I}-\mathrm{DMSO}$ complex, while DMF and GBL only functioned as solvents with relatively higher evaporation rates than that of DMSO (vapor pressure data are provided in Table 1). CB was used as a drop-casting solution to wash out surplus components remaining in solution to leave a uniform and flat intermediate-phase film [34]. Generally, to prepare the spin-coating solution, $0.530 \mathrm{~g} \mathrm{PbI}_{2}$ and $0.183 \mathrm{~g} \mathrm{MAI}$ were dissolved in $1 \mathrm{~mL}$ of the mixed solvent, and the resulting solutions were spin-coated onto the $\mathrm{FTO} / \mathrm{bl}_{-} \mathrm{TiO}_{2}$ ( $\mathrm{TiO}_{2}$ blocking layer) substrates according to a modified method [34], as described in detail in the experimental section.

The SEM images in Fig. 1 show the changes in morphology

\subsection{Perovskite solar cell fabrication}


Table 1

Physical properties of organic solvents used in the spin-coating process.

\begin{tabular}{lccccc}
\hline Solvent & $\begin{array}{c}\text { Molecular weight } \\
(\mathrm{g} / \mathrm{mol})\end{array}$ & $\begin{array}{c}\text { Density } \\
\left(\mathrm{g} / \mathrm{mL}, 25^{\circ} \mathrm{C}\right)\end{array}$ & $\begin{array}{c}\text { Boiling point } \\
\left({ }^{\circ} \mathrm{C}\right)\end{array}$ & $\begin{array}{c}\text { Vapor pressure } \\
\left(\mathrm{mmHg}, 20^{\circ} \mathrm{C}\right)\end{array}$ & $\begin{array}{c}\text { Viscosity } \\
\left(\mathrm{mPa} \cdot \mathrm{s}, 25^{\circ} \mathrm{C}\right)\end{array}$ \\
\hline DMF $\left(\mathrm{C}_{3} \mathrm{H}_{7} \mathrm{NO}\right)$ & 73.09 & 0.9445 & 153 & 2.7 & 0.8 \\
DMSO $\left(\mathrm{C}_{2} \mathrm{H}_{6} \mathrm{OS}\right)$ & 78.13 & 1.0955 & 189 & 0.42 & 2.0 \\
$\mathrm{GBL}\left(\mathrm{C}_{4} \mathrm{H}_{6} \mathrm{O}_{2}\right)$ & 86.09 & 1.124 & 204 & 1.5 & 1.7 \\
$\mathrm{CB}\left(\mathrm{C}_{6} \mathrm{H}_{5} \mathrm{Cl}\right)$ & 112.56 & 1.106 & 131 & 11.8 & $0.799\left(20^{\circ} \mathrm{C}\right)$ \\
\hline
\end{tabular}
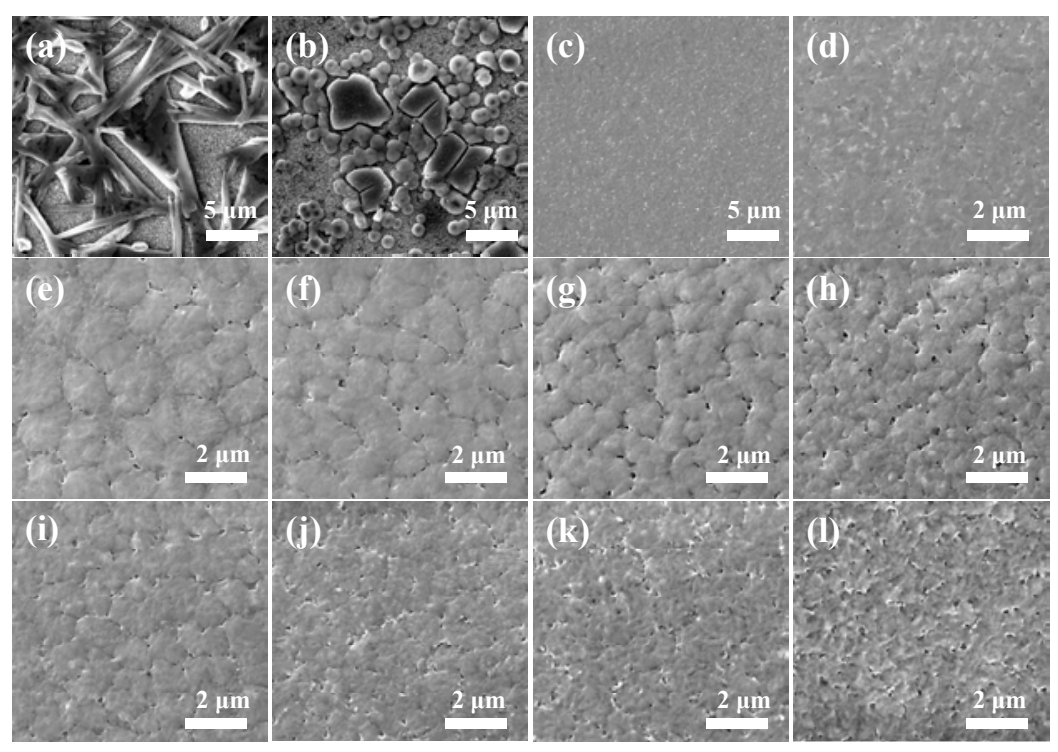

Fig. 1. SEM images of MAPbI films spin-coated using different solvents. (a) Pure DMF, (b) Pure GBL, (c) and (d) Pure DMSO, (e)-(h) DMF-DMSO mixtures containing DMF volume fractions of $20 \%, 40 \%, 60 \%$, and $80 \%$ respectively, (i)-(l) GBL-DMSO mixtures containing GBL volume fractions of $20 \%, 40 \%, 60 \%$ and $80 \%$ respectively.

of the as-prepared perovskite films. In the case of pure DMF, a number of large bundles of perovskite with length of over $5 \mu \mathrm{m}$ were woven together in a network on the surface of the substrate. When pure GBL was used, clusters of round grains with diameter of $0.5-2 \mu \mathrm{m}$ were observed. In both cases, the coverage of the substrates was very low and a large area of the substrate was left exposed, which is very unfavorable for solar cell application. When pure DMSO was used as the solvent, the surface of the perovskite film was very smooth and uniform with nearly complete substrate coverage. This was mainly ascribed to the formation of $\mathrm{PbI}_{2}$-MAI-DMSO intermediate-phase film, which retarded the rapid reaction between $\mathrm{PbI}_{2}$ and MAI during the evaporation of DMF or GBL [34]. Because of its relatively low evaporation rate and high viscosity (see Table 1), pure DMSO was not very appropriate for forming a thin film by spin-coating. Therefore, DMF and GBL were added to DMSO to study the influence of mixed solvents on the morphology of the obtained perovskite. Previous studies have demonstrated that the morphology of the perovskite exerts a significant influence on the device performance of planar-junction perovskite solar cells [27]. When 20\% 40\% DMF was added, the film surface exhibited a reasonably uniform morphology predominated by micrometer-scale polygonal grains. Statistical analysis showed that the average grain size was $1.7 \pm 0.2 \mu \mathrm{m}$ for the sample fabricated with $20 \% \mathrm{DMF}$, and $1.3 \pm 0.3 \mu \mathrm{m}$ for $40 \% \mathrm{DMF}$ in the processing solution, both values much larger than those previ- ously reported $[33,34]$. When the DMF fraction was further increased to $60 \%$, the grain size became much smaller and the grain boundaries became blurred. When the DMF fraction was further extended to $80 \%$, no clear grain boundaries could be found on the surface of the perovskite film. The use of $20 \% \sim 40 \%$ of GBL in the DMSO (Fig. 1(i) and 1(j)) led to significantly smaller grains and much more blurred grain boundaries in comparison with the corresponding samples with DMF additive. When the GBL fraction was increased to $60 \% \sim 80 \%$, more and larger pinholes were formed in the perovskite films, making the surface of the resulting films much rougher, which was expected to deteriorate the cell performance significantly.

Cross-sectional SEM images of the planar solar cells fabricated from the continuous perovskite films prepared with pure DMSO and mixed solvents are shown in Fig. 2. The thickness of the perovskite layer fabricated with pure DMSO was $\sim 300 \mathrm{~nm}$. For samples fabricated with DMF-DMSO solvent mixtures, the thickness of the perovskite film increased with the ratio of DMF to a certain degree $(\sim 330 \mathrm{~nm}$ at $40 \% \mathrm{DMF}$, and $\sim 350 \mathrm{~nm}$ at $80 \%$ DMF) Interestingly, a reverse trend occurred for the films made with GBL-DMSO solvent mixtures $(\sim 270 \mathrm{~nm}$ film thickness at $40 \% \mathrm{GBL}$ and $\sim 250 \mathrm{~nm}$ at $80 \% \mathrm{GBL}$ ). Because all three solvents had low vapor pressure at room temperature (see Table 1), the evaporation rate had limited effect on the spin-coated film thickness. Considering the very high rotation speed employed (6000 r/min), the difference in density of each 


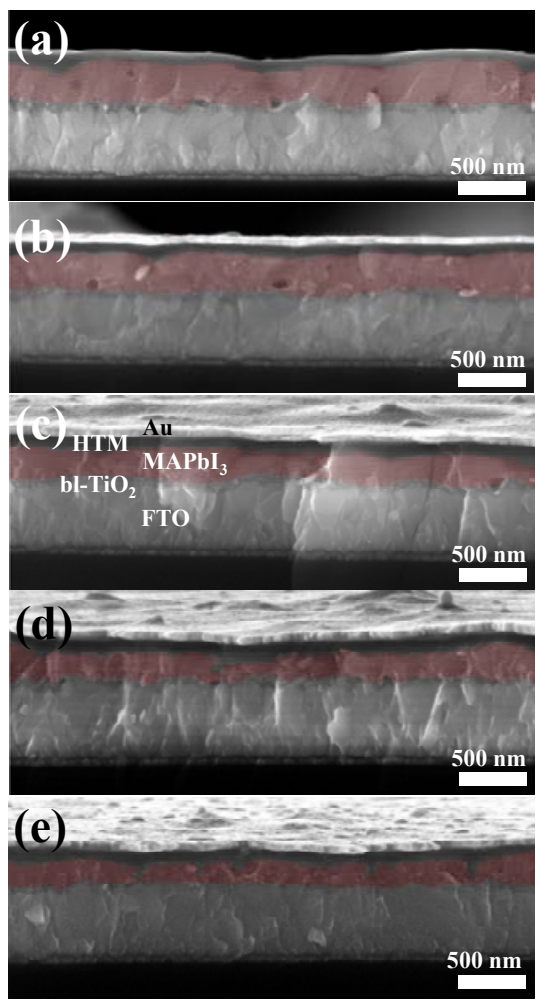

Fig. 2. Cross-sectional SEM images of planar solar cells based on perovskite films fabricated with different spin-coating solvents. (a) $80 \%$ and (b) 40\% DMF in DMF-DMSO, (c) pure DMSO, (d) $40 \%$ and (e) $80 \%$ GBL in GBL-DMSO.

solvent $(0.9445,1.0955$ and $1.124 \mathrm{~g} / \mathrm{mL}$ for DMF, DMSO, and GBL respectively, Table 1) might be the main reason for the observed variation in film thickness. It was also found from the cross-sectional SEM images that most of the pinholes had diameters no more than $100 \mathrm{~nm}$, much smaller than the perovskite layer thickness. The sample fabricated with $80 \%$ GBL in the solvent mixture exhibited more pinholes (Fig. 1(i)) and was thinner (Fig. 2(e)). Some of the pinholes even formed channels across the perovskite layer that may provide route for hole transport materials (HTMs) to penetrate through, thereby obviously increasing charge recombination and deteriorating cell performance.

To reveal the crystal structure of the as-made perovskite films, the X-ray diffraction (XRD) patterns of samples prepared with pure DMF, DMSO, and GBL and DMF-DMSO and GBL-DMSO mixtures were measured (Figs. 3(a) and 3(b)). The three intense diffractions at $14.08^{\circ}, 28.40^{\circ}$, and $31.86^{\circ}$ could be respectively assigned to the (110), (220), and (310) reflections of the tetragonal $\mathrm{MAPbI}_{3}$ phase [29]. The samples made with DMSO, both pure and mixed, exhibited $\mathrm{MAPbI}_{3}$ phase without impurities. However, MAI diffraction peaks $\left(9.77^{\circ}, 19.66^{\circ}\right)$ could be observed in the patterns of the pure DMF-processed perovskite film and a $\mathrm{PbI}_{2}$ diffraction peak $\left(12.74^{\circ}\right)$ was observed for pure GBL-processed film. These small residual phases may have been caused by the huge difference in the solubilities of the $\mathrm{PbI}_{2}$ and MAI, hence causing them to separate from the processing solution during the evaporation of the pure DMF or GBL solvents [33,34,37].

UV-Vis absorption spectra of the $\mathrm{MAPbI}_{3}$ films prepared with pure and mixed solvents are shown in Fig. 3(c). All the samples displayed absorption onsets at $\sim 800 \mathrm{~nm}$ and a sharp rise at $\sim 780 \mathrm{~nm}$, characteristic of the band-gap absorption of $\mathrm{MAPbI}_{3}$. As a result of the poor film coverage of the substrate for the samples made with pure DMF or GBL solvent, their absorption was relatively lower than those of the films fabricated with DMSO and the mixed solvents, which was more prominent in the short wavelength region (350-550 nm). Increasing the ratio of DMF enhanced the absorption intensity, while increasing the ratio of GBL reduced the absorption intensity, which was consistent with the observed trends in the variation of film thickness.

To investigate the application of the perovskite films in a photovoltaic device, a series of planar solar cells were fabricated and designated as device 1 to 11 as presented in Table 2 . The main configuration of the devices was $\mathrm{FTO} / \mathrm{bl}_{-} \mathrm{TiO}_{2}$ layer/MAPbI 3 /spiro-MeOTAD/Au (see Fig. 2(c)). The complete fabrication of the solar cell was carried out at temperatures no greater than $100^{\circ} \mathrm{C}$. This fabrication process could thus be easily extended to plastic substrates for flexible photovoltaic devices. The main photovoltaic parameters for the fabricated perovskite film-formed cells are presented in Table 2 and Fig. 4. For device 1 (made with pure DMF) and 11 (pure GBL), the values of all photovoltaic parameters U SC, $_{\mathrm{OOC}}, \mathrm{FF}, \mathrm{PCE}$, and IPCE) were much lower than those of the devices fabricated from films made with DMSO (pure and mixed solvents), which may have arisen from cell shunting and poor light absorption caused by the low coverage of the perovskite films on the substrates. Fig. 4(a) reveals that JSC was enhanced with increasing DMF content during spin-coating (device 6 to 2), and decreased with increasing GBL content (device 6 to 10), consistent with the variations in light absorption observed in Fig. 4(a). Additionally, for all devices made with DMF-DMSO (device 2 to 10), the average $V_{0 C}$ was found to be around $1.00 \mathrm{~V}$ except for a small rise to $1.03 \mathrm{~V}$ when using 20 or $40 \% \mathrm{DMF}$ in the processing solvent. Considering the very large, micrometer-scale grains and reduced grain boundaries in these cases (Fig. 1(e) and (f)), the improved $V_{0 C}$ obtained may have been caused by reduced charge recombination and energy loss. Fig. 4(c) shows that the average FF of the devices 6 to 2 decreased progressively from $79.3 \%$ to $70.5 \%$ with increasing DMF content $0 \%$ to $80 \%$ ), which probably arose from the increased recombination and series resistance in the thicker perovskite films (Fig. 2(a)-(c)). As a result, the average PCEs of the devices fabricated using DMF (device 2 to 6 ) had a peak value of $15.9 \%$ for device 4 (see Table 2 and Fig. 4(d)). In contrast, for the thinner devices made with DMSO-GBL (device 7 to 10), the FF was a little higher when the GBL volume fraction was $\leq 60 \%$. However, the FF was greatly reduced l to $\sim 70 \%$ when $80 \%$ GBL was used in the solvent mixture (device 10). This may have been caused by the increased number of pin-holes in the film (Figs. 1(l) and $2(\mathrm{e}))$ and enhanced charge recombination in the cells. The average PCEs of the devices (6 to 10) decreased with increasing GBL content. Fig. 4(e) shows typical $J-V$ curves of the devices made with pure solvents and some of those made with mixed 

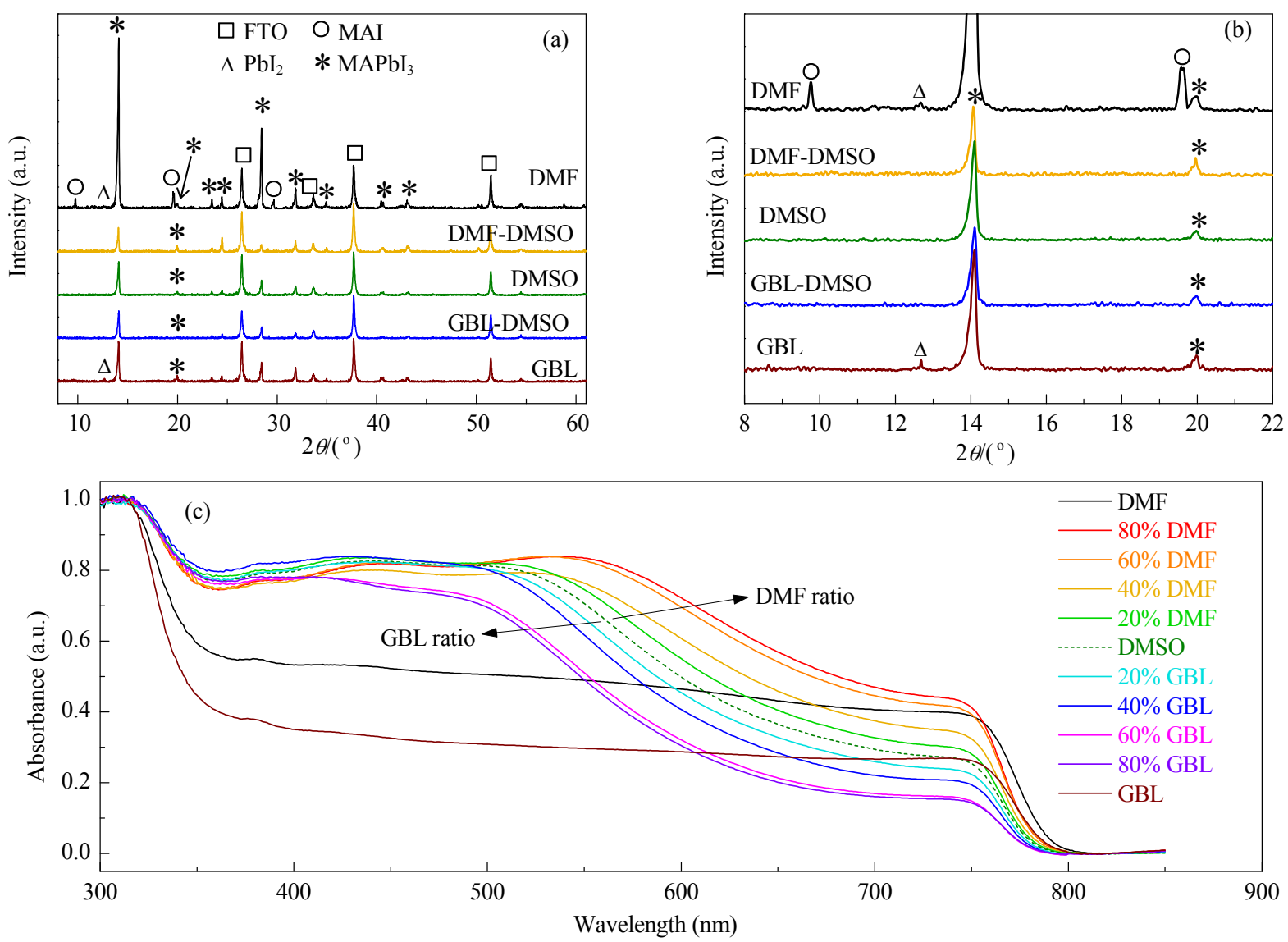

Fig. 3. (a) XRD patterns of $\mathrm{MAPbI}_{3}$ films spin-coated with pure solvents (DMF, DMSO, and GBL) and mixed solvents (DMF-DMSO and GBL-DMSO with

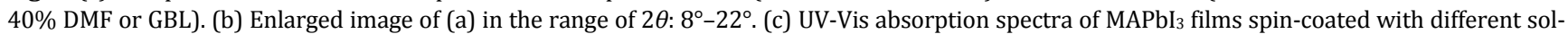
vents: pure DMF, (80-20) \% DMF in DMF-DMSO, pure DMSO (dashed curve), (20-80) \% GBL in GBL-DMSO, and pure GBL.

Table 2

Average photovoltaic parameters with standard deviations obtained with different spin-coating solvents. At least 8 identical devices were measured in each case.

\begin{tabular}{|c|c|c|c|c|c|c|c|c|}
\hline \multirow{2}{*}{ No. } & \multicolumn{3}{|c|}{ Volume fraction (\%) } & \multirow{2}{*}{$J_{\mathrm{sc}}\left(\mathrm{mA} / \mathrm{cm}^{2}\right)$} & \multirow{2}{*}{$V_{\mathrm{OC}}(\mathrm{V})$} & \multirow{2}{*}{$\mathrm{FF}(\%)$} & \multirow{2}{*}{ PCE (\%) } & \multirow{2}{*}{$\mathrm{PCE}_{\max }(\%)$} \\
\hline & DMF & DMSO & GBL & & & & & \\
\hline 1 & 100 & 0 & - & $13.0 \pm 0.5$ & $0.86 \pm 0.01$ & $59.5 \pm 6.2$ & $6.7 \pm 0.8$ & 7.9 \\
\hline 2 & 80 & 20 & - & $19.8 \pm 0.3$ & $1.00 \pm 0.02$ & $70.5 \pm 7.7$ & $14.0 \pm 1.6$ & 16.2 \\
\hline 3 & 60 & 40 & - & $19.5 \pm 0.3$ & $1.01 \pm 0.02$ & $75.6 \pm 2.8$ & $14.9 \pm 0.9$ & 16.1 \\
\hline 4 & 40 & 60 & - & $19.8 \pm 0.2$ & $1.03 \pm 0.01$ & $77.8 \pm 1.8$ & $15.9 \pm 0.4$ & 16.5 \\
\hline 5 & 20 & 80 & - & $19.0 \pm 0.1$ & $1.03 \pm 0.01$ & $78.8 \pm 0.9$ & $15.5 \pm 0.3$ & 15.9 \\
\hline 6 & 0 & 100 & 0 & $18.3 \pm 0.2$ & $1.01 \pm 0.02$ & $79.3 \pm 1.2$ & $14.7 \pm 0.3$ & 15.1 \\
\hline 7 & - & 80 & 20 & $17.9 \pm 0.2$ & $1.00 \pm 0.01$ & $77.7 \pm 0.9$ & $13.8 \pm 0.2$ & 14.1 \\
\hline 8 & - & 60 & 40 & $17.0 \pm 0.2$ & $1.00 \pm 0.01$ & $79.9 \pm 1.1$ & $13.6 \pm 0.2$ & 13.8 \\
\hline 9 & - & 40 & 60 & $16.3 \pm 0.3$ & $1.00 \pm 0.01$ & $79.9 \pm 1.7$ & $13.0 \pm 0.3$ & 13.4 \\
\hline 10 & - & 20 & 80 & $16.7 \pm 0.1$ & $0.99 \pm 0.02$ & $70.4 \pm 7.0$ & $11.6 \pm 1.3$ & 13.1 \\
\hline 11 & - & 0 & 100 & $13.2 \pm 0.5$ & $0.87 \pm 0.02$ & $71.9 \pm 8.8$ & $8.3 \pm 1.1$ & 9.0 \\
\hline
\end{tabular}

solvents (Table 2). The IPCE spectra (Fig. 4(f)) of these devices all displayed an onset at about $800 \mathrm{~nm}$ and a sharp rise around $780 \mathrm{~nm}$, reaching a peak value of over $85 \%$ at about $480 \mathrm{~nm}$, confirming the high charge production and collection efficiencies of the devices.

The best-performing devices (40\% DMF in DMF-DMSO, device 4) exhibited a maximum PCE (PCEmax) of $16.5 \%$, with a Jsc of $19.8 \mathrm{~mA} / \mathrm{cm}^{2}, V_{\mathrm{OC}}$ of $1.05 \mathrm{~V}$, and FF of $79.3 \%$ obtained from the $J-V$ curve (Fig. 5(a)), under reverse scan at $\sim 0.1 \mathrm{~V} / \mathrm{s}$ and standard AM 1.5 conditions. We further characterized the hysteresis in the $J-V$ curves by sweeping the applied voltage in forward scan, obtaining $19.8 \mathrm{~mA} / \mathrm{cm}^{2}$ (Jsc), $0.96 \mathrm{~V}$ (Voc), $62.3 \%$ (FF), and $11.9 \%$ (PCE) for this cell. It has been demonstrated that reverse scanning of a perovskite solar cell will overestimate the PCE, while forward scanning results in an underestimate [34]. The most accurate evaluation of device efficiency is 

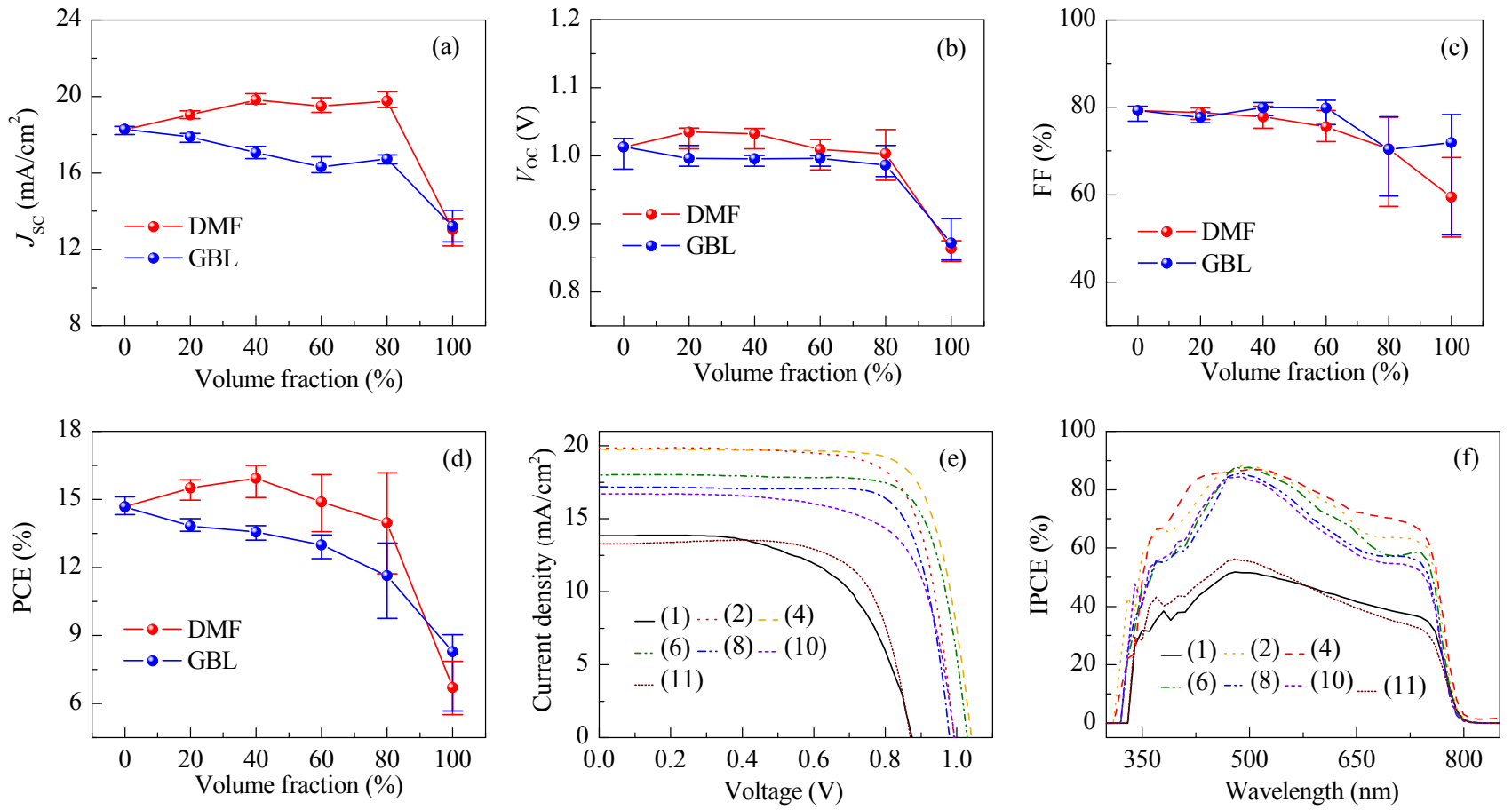

Fig. 4. Dependence of the main photovoltaic parameters on the volume fraction of DMF or GBL in the mixed spin-coating solvent with DMSO. (a) Short-circuit current density (Jsc); (b) Open circuit voltage (Voc); (c) Fill factor (FF); and (d) power conversion efficiency (PCE); (e) $J-V$ curves; (f) Incident-photon-to-current conversion efficiency (IPCE) spectra for the devices made with (1) pure DMF, (2) 80\% DMF, (4) 40\% DMF, (6) pure DMSO, (8) 40\% GBL, (10) 80\% \% GBL, and (11) pure GBL, as designated in Table 2.
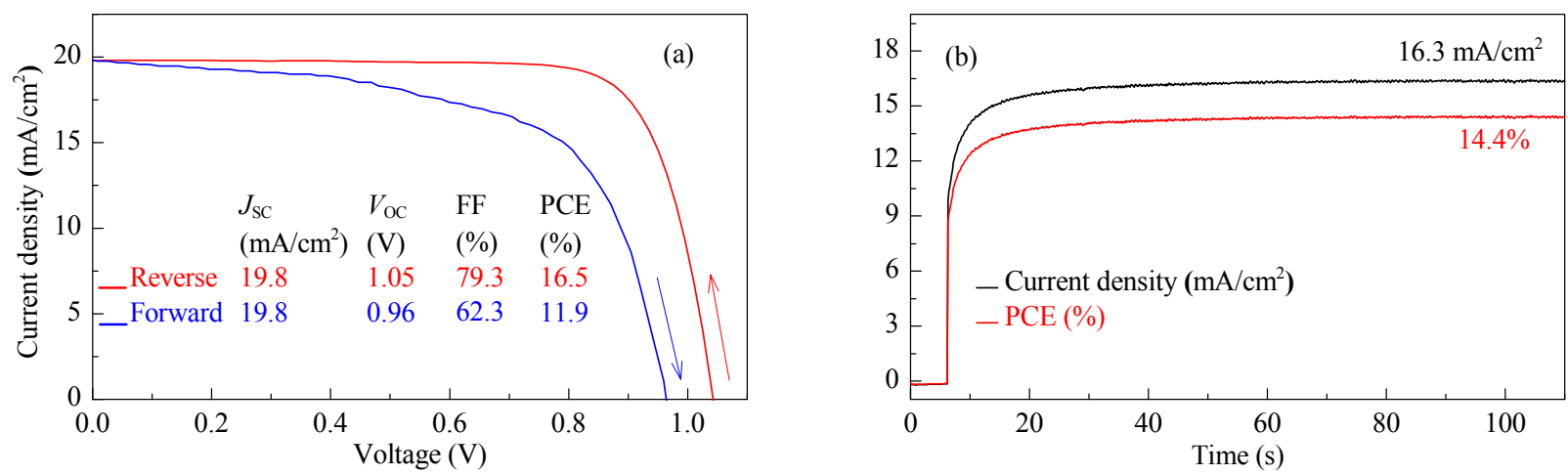

Fig. 5. Photovoltaic performance of the best cell (40\% DMF in DMSO, device 4). (a) $J-V$ curves obtained from reverse scan and forward scan under simulated AM 1.5 G solar irradiation. (b) Steady-state photocurrent density and PCE measured as a function of time for the same cell held at a maximum power point $(0.88 \mathrm{~V})$. The cell was placed in the dark prior to the start of the measurement.

to measure its power output under working conditions (i.e., stabilized conditions). Therefore, the photocurrent of the cell was also recorded at a fixed forward bias of $0.88 \mathrm{~V}$ (Fig. 5(b)). The photocurrent stabilized within a short time to about 16.3 $\mathrm{mA} / \mathrm{cm}^{2}$, yielding a power conversion efficiency of $14.4 \%$ after over $100 \mathrm{~s}$ of irradiation, which was higher than reported data for similar device structures $[33,36]$.

\section{Conclusions}

We have described the solvent engineering of mixed solvents (DMF-DMSO and GBL-DMSO) for spin-coating of uniform perovskite films. Both the grain size and film thickness varied significantly with the volume fraction of the mixed solvents. At
20\% 40\% DMF in DMSO, micrometer-scale perovskite grains and reduced grain boundaries were observed in the obtained films, and the final devices yielded average PCEs of over $15 \%$, a highest PCE of $16.5 \%$ during reverse scan, and a stabilized PCE of $14.4 \%$ at $0.88 \mathrm{~V}$ under standard AM 1.5 conditions. Because the perovskite film solar cells exhibited high device performance and were fully fabricated at temperatures no greater than $100{ }^{\circ} \mathrm{C}$, the present perovskite solar cells show promise for flexible devices and tandem solar cells.

\section{References}

[1] Kojima A, Teshima K, Shirai Y, Miyasaka T. J Am Chem Soc, 2009, 131: 6050 


\section{Graphical Abstract}

Chin. J. Catal., 2015, 36: 1183-1190 doi: 10.1016/S1872-2067(15)60929-9

\section{Solvent engineering of spin-coating solutions for planar-structured high-efficiency perovskite solar cells}

Bing Cai, Wen-Hua Zhang, Jieshan Qiu*

Dalian University of Technology; Dalian Institute of Chemical Physics, Chinese Academy of Sciences
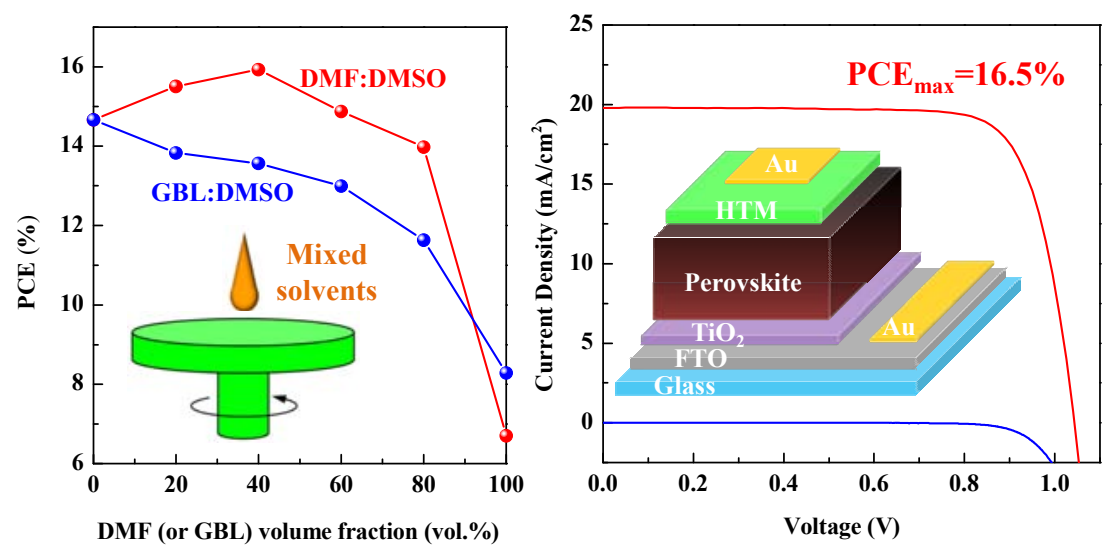

A systematic mixed solvent engineering study has been performed to produce uniform $\mathrm{CH}_{3} \mathrm{NH}_{3} \mathrm{PbI}_{3}$ film by a spin-coating approach, resulting in planar-structured perovskite solar cells with high power conversion efficiency.

[2] Lee M M, Teuscher J, Miyasaka T, Murakami T N, Snaith H J. Science, 2012, 338: 643

[3] Noh J H, Im S H, Heo J H, Mandal T N, Seok S I. Nano Lett, 2013, 13: 1764

[4] Jeon N J, Noh J H, Yang W S, Kim Y C, Ryu S, Seo J, Seok S I. Nature, 2015, 517: 476

[5] Zuo F, Williams S T, Liang P-W, Chueh C-C, Liao C-Y, Jen A K-Y. Adv Mater, 2014, 26: 6454

[6] Heo J H, Im S H, Noh J H, Mandal T N, Lim C S, Chang J A, Lee Y H, Kim H J, Sarkar A, Nazeeruddin M K, Gratzel M, Seok S I. Nat Photonics, 2013, 7: 487

[7] Cai B, Xing Y D, Yang Z, Zhang W H, Qiu J S. Energy Environ Sci, 2013, 6: 1480

[8] Jeon N J, Lee J, Noh J H, Nazeeruddin M K, Gratzel M, Seok S I. J Am Chem Soc, 2013, 135: 19087

[9] Ryu S C, Noh J H, Jeon N J, Kim Y C, Yang S, Seo J W, Seok S I. Energy Environ Sci, 2014, 7: 2614

[10] Cai B, Zhong D, Yang Z, Huang B K, Miao S, Zhang W H, Qiu J S, Li C. J Mater Chem C, 2015, 3: 729

[11] Xu Y Z, Shi J J, Lv S T, Zhu L F, Dong J, Wu H J, Xiao Y, Luo Y H, Wang S R, Li D M, Li X G, Meng Q B. ACS Appl Mater Interfaces, 2014, 6: 5651

[12] Kim H S, Lee C R, Im J H, Lee K B, Moehl T, Marchioro A, Moon S J, Humphry-Baker R, Yum J H, Moser J E, Graetzel M, Park N G. Sci Rep, 2012, 2: 591

[13] Mei A Y, Li X, Liu L F, Ku Z L, Liu T F, Rong Y G, Xu M, Hu M, Chen J Z, Yang Y, Gratzel M, Han H W. Science, 2014, 345: 295

[14] Liu L F, Mei A Y, Liu T F, Jiang P, Sheng Y S, Zhang L J, Han H W. J Am Chem Soc, 2015, 137: 1790

[15] Shi J J, Dong J, Lv S T, Xu Y Z, Zhu L F, Xiao J Y, Xu X, Wu H J, Li D M, Luo Y H, Meng Q B. Appl Phys Lett, 2014, 104: 063901

[16] Zhong D, Cai B, Wang X L, Yang Z, Xing Y D, Miao S, Zhang W H, Li C. Nano Energy, 2015, 11: 409

[17] Liu M Z, Johnston M B, Snaith H J. Nature, 2013, 501: 395

[18] Marchioro A, Teuscher J, Friedrich D, Kunst M, van de Krol R,
Moehl T, Gratzel M, Moser J E. Nat Photonics, 2014, 8: 250

[19] Stranks S D, Eperon G E, Grancini G, Menelaou C, Alcocer M J P, Leijtens T, Herz L M, Petrozza A, Snaith H J. Science, 2013, 342: 341

[20] Xing G C, Mathews N, Sun S, Lim S S, Lam Y M, Gratzel M, Mhaisalkar S, Sum T C. Science, 2013, 342: 344

[21] Eperon G E, Stranks S D, Menelaou C, Johnston M B, Herz L M, Snaith H J. Energy Environ Sci, 2014, 7: 982

[22] Yang Z, Zhang W H. Chin J Catal (杨周, 张文华. 催化学报), 2014, 35: 983

[23] Liu D Y, Kelly T L. Nat Photonics, 2014, 8: 133

[24] Docampo P, Ball J M, Darwich M, Eperon G E, Snaith H J. Nat Commun, 2013, 4: 2761

[25] Todorov T, Gershon T, Gunawan O, Sturdevant C, Guha S. Appl Phys Lett, 2014, 105: 173902

[26] Loper P, Moon S J, de Nicolas S M, Niesen B, Ledinsky M, Nicolay S, Bailat J, Yum J H, De Wolf S, Ballif C. Phys Chem Chem Phys, 2015, 17: 1619

[27] Eperon G E, Burlakov V M, Docampo P, Goriely A, Snaith H J. Adv Funct Mater, 2014, 24: 151

[28] Zhao Y X, Zhu K. J Phys Chem Lett, 2014, 5: 4175

[29] Burschka J, Pellet N, Moon S J, Humphry-Baker R, Gao P, Nazeeruddin M K, Gratzel M. Nature, 2013, 499: 316

[30] Xu Y Z, Zhu L F, Shi J J, Lv S T, Xu X, Xiao J Y, Dong J, Wu H J, Luo Y H, Li D M, Meng Q B. ACS Appl Mater Interfaces 2015, 7: 2242

[31] Chen Q, Zhou H P, Hong Z R, Luo S, Duan H S, Wang H H, Liu Y, Li G, Yang Y.J Am Chem Soc, 2014, 136: 622

[32] Du T, Wang N, Chen H J, Lin H, He H C. ACS Appl Mater Interfaces, 2015, 7: 3382

[33] Xiao M D, Huang F Z, Huang W C, Dkhissi Y, Zhu Y, Etheridge J, Gray-Weale A, Bach U, Cheng Y B, Spiccia L. Angew Chem Int Edit, 2014, 53: 9898

[34] Jeon N J, Noh J H, Kim Y C, Yang W S, Ryu S C, Seol S I. Nat Mater, 2014, 13: 897

[35] Wu Y Z, Islam A, Yang X D, Qin C J, Liu J, Zhang K, Peng W, Han L Y. Energy Environ Sci, 2014, 7: 2934 
[36] Yella A, Heiniger L P, Gao P, Nazeeruddin M K, Gratzel M. Nano Letters, 2014, 14: 2591
[37] Shen D H, Yu X, Cai X, Peng M, Ma Y Z, Su X, Xiao L X, Zou D C. J Mater Chem A, 2014, 2: 20454

\title{
平板结构高效钻钛矿太阳能电池的旋涂溶液溶剂工程
}

\author{
蔡 冰 ${ }^{\mathrm{a}, \mathrm{b}}$, 张文华 ${ }^{\mathrm{b}}$, 邱介山 ${ }^{\mathrm{a},{ }^{*}}$ \\ ${ }^{\mathrm{a}}$ 大连理工大学, 精细化工国家重点实验室, 能源材料化工辽宁省重点实验室, 碳素材料实验室, 辽宁大连 116024 \\ ${ }^{\mathrm{b}}$ 中国科学院大连化学物理研究所催化基础国家重点实验室, 洁净能源国家实验室, 辽宁大连 116023
}

摘要: 自2009年首次应用于太阳能电池中以来, 有机铅卤化物钙钛矿材料得到了极大关注. 据文献报道, 有机铅卤化物钻钠矿材 料在不同结构的太阳能电池中都得到了应用, 其中与有机太阳能电池类似的平板结构钻钛矿具有结构简单、制备容易等优点, 非 常适合用于柔性电池和多节电池等各种应用. 在平板结构的太阳能电池中, 制备高质量的钻钛矿薄膜至关重要. 真空热蒸镀法虽 然可以制备厚度均匀的钻钛矿薄膜, 获得高的器件性能, 但是设备成本较高, 不利于大规模生产. 而在溶液法中, 早期的一步旋涂 法和两步法由于没有多孔金属氧化物的支撑, 很难制备均匀的钙钛矿平板薄膜; 而气相辅助的两步法虽然制备的薄膜比较均匀, 但反应时间却比较长. 程一兵研究组采用在旋涂 $N, N$ 二 二甲基甲酰胺(DMF)溶液时滴加氯苯使钙钛矿快速析出结晶的方法, 制备了 高质量的均匀的 $\mathrm{CH}_{3} \mathrm{NH}_{3} \mathrm{PbI}_{3}$ 薄膜. Seok研究组采用1,4-丁内酯(GBL)和二甲基亚砜(DMSO)的混和溶剂, 在旋涂时滴加甲苯的方 法, 在多孔二氧化钛上也制得了均匀的 $\mathrm{CH}_{3} \mathrm{NH}_{3} \mathrm{PbI}_{3}$ 薄膜, 取得了很高转化效率 (16.7\%), 但缺少对不同溶剂比例的细致研究, 另外, 也没有对平板结构电池性能进行研究.

本文采用DMF-DMSO和GBL-DMSO作为混合溶剂在二氧化钛致密层上旋涂制备了平板结构的䥻钛矿薄膜, 并且对混合溶剂 的比例对器件性能的影响进行了详细的考察和优化. 当纯DMF或纯GBL作为旋涂溶剂时, 得到的 $\mathrm{CH}_{3} \mathrm{NH}_{3} \mathrm{PbI}_{3}$ 钙钛矿薄膜含有大 量不连续的晶粒, 表面的覆盖度很差, 对入射光的吸收远弱于连续均匀的薄膜. 而且XRD结果表明, 纯DMF或纯GBL作为旋涂溶 剂的薄膜残留有前驱体的杂质, 对器件性能非常不利. 而采用DMSO作为旋涂溶剂时, 制得的薄膜表面则比较均匀, 几乎达到 $100 \%$ 的覆盖. 这主要是由于在旋涂溶液中形成了 $\mathrm{PbI}_{2}-\mathrm{CH}_{3} \mathrm{NH}_{3} \mathrm{I}-\mathrm{DMSO}$ 的中间相, 这样可以避免纯DMF或纯GBL溶剂蒸发时 $\mathrm{PbI}_{2}$ 和 $\mathrm{CH}_{3} \mathrm{NH}_{3}$ I的剧烈反应, 因此退火后制得的 $\mathrm{CH}_{3} \mathrm{NH}_{3} \mathrm{PbI}_{3}$ 薄膜非常均匀. 然而由于纯DMSO的高粘度和低挥发速度, 并不是非常适 合作为旋涂溶剂, 因此我们将DMF和GBL加入到DMSO中形成混合溶剂来考察对制备的钙钛矿薄膜质量和器件性能的影响. 扫 描电镜结果表明, 加入 $20 \%$ 40\%体积分数的DMF时, 形成的薄膜表面非常均匀而且晶粒尺寸很大, 达到微米级别, 这样有利于减 少晶界处的复合, 提高电池性能. 继续增加DMF比例会导致晶粒减小, 晶界和孔隙增多, 薄膜表面也更加粗粘. 而加入GBL时得 到的晶粒要远小于加入DMF时的尺寸, 并且随着GBL比例的增加, 薄膜的表面变得更加粗精, 孔隙明显增多, 严重影响电池性能. XRD结果表明, 纯DMSO和混合溶剂制得的薄膜都没有前驱体的残留. 紫外可见吸收光谱表明, 随着DMF比例的增加, 吸收逐渐 增强; 而随着GBL比例的增加, 吸收逐渐减弱. 这主要由于不同比例溶剂制得的薄膜厚度有所差异造成的.

由相关的薄膜制备的平板结构太阳能电池 $I-V$ 测试表明: 当使用DMF-DMSO混合溶剂时, 随着DMF比例由 $0 \%$ 增至 $40 \%$, 短路 电流和开路电压逐渐增加, 填充因子略微减小, 总体上导致光电转化效率逐渐增大. 随着DMF继续增多, 开路电压和填充因子的 减小导致转化效率逐渐降低. 而当使用GBL-DMSO混合溶剂时, 主要受到短路电流的影响, 电池的效率明显低于含DMF的混合 溶剂的情况, 而且随着GBL增多, 电池效率逐渐降低. 电池的最高转化效率达到了 $16.5 \%$, 最高功率点下固定电压扫描得到的稳态 效率也达到了 $14.4 \%$, 高于报道中采用类似结构的电池的性能. 由于在整个电池制备过程中, 整个实验过程都低于 $100{ }^{\circ} \mathrm{C}$, 该方法 非常适合未来推广到柔性太阳能电池和多节太阳能电池上.

关键词: 钙钣矿; 薄膜; 太阳能电池; 溶剂工程; 形貌; 器件性能

收稿日期: 2015-05-21；接受日期：2015-06-16; 出版日期：2015-08-20

*通讯联系人. 电子信箱: jqiu@dlut.edu.cn

基金来源：国家自然科学基金(21336001, 20873141).

本文的英文电子版由Elsevier出版社在ScienceDirect上出版(http://www.sciencedirect.com/science/journal/18722067). 